Grzegorz BYWALEC, PhD, Professor UL

Faculty of International and Political Studies, University of Lodz

e-mail: grzegorz.bywalec@uni.lodz.pl

ORCID: 0000-0001-8604-6613

DOI: $10.15290 /$ oes.2020.03.101.10

\title{
DYNAMICS AND DETERMINANTS OF TRADE EXCHANGE BETWEEN THE EUROPEAN UNION AND INDIA ${ }^{1}$
}

\begin{abstract}
Summary
Purpose - This article attempts to identify and assess trade exchange between the European Union and India, including an indication of the main determinants of the process.

Research method - Descriptive analysis based on numerical data from various statistical sources together with a review of specialist literature.

Results - Trade exchange between the EU and India is particularly important for India. Exports to the EU account for around $17-20 \%$ of Indian exports in total. On the other hand, the EU's share in Indian imports amounts to $10-12 \%$ of all imported goods. Trade with India looks different from the EU side. India's share in both exports and imports presents a margin for EU trade in goods of 2-3\%. The share of services in the trade between the EU and India is high. It accounts for $25-30 \%$ of mutual turnover. These are usually modern services based on the offshoring principles, such as IT, business, transport, consulting, science, and tourism. Among the European Union Member States, India's main trading partners in goods are Germany, the United Kingdom, Belgium, France, the Netherlands, and Italy. These six countries account for ca. $85 \%$ of the EU-India trade exchange. In 2007, negotiations started to create an EU-India Free Trade Area. Due to the large differences in the positions of both parties, these discussions were not finalised and were subsequently suspended in 2013. However, after the reactivation of talks in 2016, there is still a possibility for the creation of an EU-India Free Trade Area of 1.8 billion people.

Originality / value / implications / recommendations - At the beginning of the 21 st century, in terms of GDP (according to PPP), the European Union (understood as one economic entity) became the second largest economic power globally (after China), while India advanced to fourth position (after China, the EU and the USA). An analysis of trade exchange between these two economic powers allows for a clearer understanding of the modern global economy, as well as the processes and mechanisms of its functioning.
\end{abstract}

Keywords: European Union, India, trade exchange, economic policy, economic reforms

JEL Classification: F10, F13, F14, O11

1 Article received on 29 March 2020, accepted on 29 May 2020. 


\section{Introduction}

In the last two decades, both the European Union and India have grown to positions of global economic superpowers, and hence enjoy a considerable influence on the shape of international trade relations and development processes. Therefore, the study of the economic development of the EU and India, as well as their mutual relations, has become an important topic within global economics.

Based upon the above, this article attempts to identify and assess trade exchange between the European Union (understood as a single economic entity) and India, together with the determinants of these processes ${ }^{2}$. The main attention focused on the most recent period, i.e. after 2000, when after thorough reforms in the European Union and India in the 1990s, there was an acceleration of economic exchange between these two entities.

Thus, the formulated research problem is poorly represented in economic literature, not only Polish or Indian, but also worldwide. The goal of this article is to reduce this gap.

\section{The rationale and history of EU-Indian economic relations}

In the first decade of the 21 st century, the European Union (the EU) became the world's largest economic power. However, in 2015 it lost this position to the Chinese economy. In 2018, according to the Purchasing Power Parity (PPP) method adopted for calculations, EU countries generated $16.5 \%$ of the gross world product (GWP), which ranks the EU economy second in the world behind China, where $18.6 \%$ of GWP was generated, and ahead of nations such as the USA (15.1\%), India (7.7\%), Japan (4.0\%), Russia (3.0\%), Indonesia (2.6\%) and Brazil (2.5\%) [www 5, author's own calculations].

The European Union has a population greater than 500 million people, which ranks it third in world demographic statistics (after China and India). Whilst the majority of EU economies are amongst the most developed in the world their development dynamics are low. The GDP growth rate of the entire EU was at the level of $2 \%-3 \%$ per annum during the period 2000-2008, although in several countries, mainly the smaller countries who joined the EU after 2004, the GDP growth sometimes exceeded $10 \%$. The European Union economy was strongly affected by the crisis in 2008-2009, which resulted in absolute falls in GDP by about $4.0 \%$ on average for the whole area, and in some countries (mainly the Baltic states) by as much as $10 \%-15 \%$. However, in the second decade of the 21 st century there was a low but systematic growth of the European Union's GDP (according to PPP), on average by $2.0 \%$ per year [Trade and Development Report..., 2019, p. 2].

India gained its independence in 1947. From the beginning, it has been a democratic state, a republic with a federal structure (union of states). For four decades

${ }^{2}$ Herein, "trade exchange" is limited to trade in goods and services. 
(until 1991), the economic system in India was based on strong state intervention in the economy, central planning and far-reaching autarky, called the "Indian socialism". However, the implementation of this economic programme did not yield the expected results. The rate of economic growth at 3\%-4\% per annum was low, which meant that India lagged behind other Asian countries. This was reflected in the decreasing share of India in the continent's economy. Between 1950 and 1990, India's share in Asia's GDP (57 countries) decreased from 22.6\% to 12.7\% [Bywalec, 2015, p. 94]. The breakthrough only came in the last decade of the 20th century as a result of radical economic and political reforms initiated in 1991, known as the "new economic policy", which meant the liberalisation of the economy, its deregulation, and also administrative decentralisation of the state (creation of a democratic local government). As a result of the new economic policy after 1991, the annual GDP growth rate in India increased significantly and between 1993 and 2019 it ranged from 5 to $10 \%$, i.e. it was more than twice the world average. A significant decrease in the growth rate took place in 2001-2002 (world recession due to the bursting of the "dot-com bubble") and in 2008 (world financial crisis). Among the big world economies, only the Chinese economy had high GDP growth rates [Trade and Development Report..., 2019, p. 2].

The rapid economic development after 1991 propelled India to the top of the world. In 2008, India's GDP (in PPP terms) exceeded Japan's GDP, and since then the gap between the two countries has been increasing. However, if the EU was not treated as one entity and only as individual member states, India would be even higher in this global classification, ranked third in the world with the GDP higher than in any EU member state. It is worth noting that Germany, the UK or France (the EU's largest economies) were distanced by India after 1998, which is probably the most convincing evidence of the success of the reforms launched in 1991.

For several years, the economic histories of India and the European Economic Community (EEC - the predecessor of the EU) developed as if alongside each other in parallel. The EEC countries and India were troubled by their own internal or regional challenges. That should not be the case any longer in an era of advanced globalisation. These two large players, with their extended intersectoral complementarity of economic structures, should cooperate closely if they want to function rationally and play a significant role in the world economy.

The year 1962, when India was the first developing country to establish diplomatic relations with the European Economic Community, should be considered an important date in EEC-India relations. However, their scale of economic cooperation was moderate. The situation changed after 1973, when the United Kingdom was admitted into the EEC. The UK maintained close economic relations with India, a recent colony, and a member of the Commonwealth. In 1981, a five-year economic cooperation agreement was signed between the EEC and India, which was significantly expanded in 1985. In 1983, a permanent representation of the EEC was established in Delhi. However, trade and capital movements between the European Union and India were still insignificant. The EEC countries imported primarily agricultural products (cotton, jute, tea, spices), textiles, cotton and leather 
clothes, wood, furniture, pearls and precious stones from India. EU exports to India were limited to certain machinery and equipment, clothing, transport and food. The majority of the machinery and equipment, transport, weapons, construction materials and technology (including complete industrial facilities) were imported to India from the Soviet Union and the socialist countries of Eastern Europe with whom India had good political and economic relations. In the 1980 s, about $40 \%$ of Indian export was directed to these markets [Bywalec, 2015, p.104].

Cooperation accelerated after 1991, when the EEC and India underwent major political and economic reforms. A special role was played by the "new economic policy" in India implemented in 1991, which departed from the centralised and autarkic economy. Many quantitative restrictions in foreign trade and capital turnover (mainly export and import licences) were abolished, extremely high customs tariffs were reduced, fixed exchange rates were abandoned, and trade procedures were made less bureaucratic. These changes resulted in a dynamic development of India's foreign trade, which in 1992-2000 increased almost fourfold [Singh, 2014, pp. 1213]. An important milestone was the agreement on partnership and development concluded between India and the European Union (transformed from the EEC) in 1993. Since 2000, regular annual political meetings have been held at the highest government level, alternately in the European Union and India, i.e. the so-called EU-India summits (with a break in 2013-2015). These summits are always accompanied by numerous conferences and business meetings. It should be added that, on the Indian side, the EU's trade relations with China actively growing since the 1990s, have become an important stimulus for the development of cooperation with the European Union. India feared that the rapidly growing competition from Chinese companies on the European market would impair the situation of Indian exporters and investors, while European companies would become less interested in the Indian market.

After 2007, the EU-India Free Trade Agreement became the ultimate objective of economic negotiations between the European Union and India. However, these negotiations have proved to be complex [Felbermayr et al., 2016, p. 13]. India does not want to agree on the full opening of its market, i.e. the elimination or significant reduction of quotas and custom duties on many goods from the European Union, especially food products, textiles and clothing, cars and alcohol. Free access of the EU concerns to these segments of the Indian market would result in an inflow of cheaper EU food and other goods of agricultural origin, which would painfully hit Indian agriculture, crafts, crop processing and, in the case of means of transport, would also hinder the development of the domestic automotive industry. This resistance was additionally justified by the protectionism of the European Union in relation to its agriculture and agricultural exports (e.g. subsidies for agricultural production). The effect of such a policy would be the deprivation of millions of Indian families living from agriculture, agri-food processing, crafts or light industry for their livelihoods, which would destabilise the Indian economy, as well as social and political life. India is also opposed to restricting access to the European market for Indian services (mainly IT, financial, medical, construction) and the employment of 
Indian professionals in these sectors. On the other hand, the EU calls for the inclusion in the FTA of the so-called social and environmental clauses which, inter alia, prevent the entry into the EU of goods produced using child labour and goods produced to the detriment of the environment. The Indians do not want to agree to the broad opening of their market to insurance and public procurement. Misunderstandings and conflicts also result from frequent violations of the protection of personal data and intellectual property rights (copyright, patents and trademarks) by certain Indian manufacturers and distributors, both domestically and externally; in particular, the Indian pharmaceutical industry produces large quantities of generic medicines, i.e. much cheaper substitutes for original medicines. The EU side demands an absolute respect for these rights, which is usually not understood by the Indians. Indian customs tariffs (still high, albeit systematically reduced), as well as a wide range of non-tariff activities are yet another obstacle to the development of EU-India trade after 2000. The Indian authorities do not want to reduce the duties significantly, not only to protect the market for their own products, but also for fiscal reasons, since they still represent a significant share of their budget revenue. A number of Indian business communities and politicians from right-wing parties, mainly the Indian People's Party (BJP), which seized power after the 2014 parliamentary elections and won again in 2019, have spoken out against the liberalisation of trade with the European Union [Domżalski, 2017, pp. 382-385]. The so-called import substitution (dating back to the period of 'Indian socialism'), i.e. the substitution of foreign goods with domestic production, continues to play an important role in the economic policy of BJP. This is reflected in the "Make in India" programme announced by the new right-wing government in September 2014. Its aim is to reindustrialise India, i.e. to accelerate the development and modernisation of the industry and thus reduce its dependence on import. Under this scheme, 25 priority economic sectors have been identified, in which investment and production are particularly encouraged by both central and state authorities.

Moreover, after the negative experience of the global economic crisis of 20082009 , India has modified its trade policy and does not want to become too dependent on one large partner, i.e. the European Union. It wants to diversify its foreign trade and, above all, develop contacts with its closer, i.e. Asian environment, such as the countries of South-East Asia or Western Asia (mainly the Gulf States) and East Africa, and also to reactivate the once active economic contacts with Russia. India has also commenced negotiations to create an India-US Free Trade Area.

In view of numerous conflicting interests and practical problems, negotiations on the establishment of the EU-India Free Trade Area were suspended in 2013. [Pant, 2016, p. 69]. The project was reactivated in 2016, which was reflected in the EU-India Summit in Brussels, as well as further summits which took place in the following years. However, despite regular negotiations at the highest level, so far (2020) there is no chance of a successful conclusion of the free trade negotiations and the creation of a large market encompassing 1.8 billion people, which is almost a quarter of the world's population. 


\section{EU and India foreign trade in the global context}

One of the basic measures of the importance of any economy on the international scene is its participation in world trade. To make such an assessment of the $\mathrm{EU}$ and India, indicators of their respective shares in the world trade in goods and services have been summarised in table 1 .

The data in table 1 show huge differences in the shares of India and the European Union in international trade. It must come as a surprise that India, the third largest economy in the world with its GDP being only half of that of the EU as a whole, accounts for only $1.0 \%-2.6 \%$ of the world trade in goods and services during the period under review. Despite its great progress after 1991, India is still poorly integrated into the world economy and in that respect, it is trailing behind many countries in its close geographic environment.

By contrast, the European Union's foreign trade is involved in about $1 / 3$ of the world trade in goods and services, but in the second decade of this century the share indicators are already 4-5 percentage points lower than in the first decade.

TABLE 1

Selected indicators of foreign trade in goods and services for the European Union and India (in \%, current prices in USD)

\begin{tabular}{|l|l|c|c|c|c|c|c|}
\hline \multicolumn{2}{|c|}{ Specification } & $\mathbf{2 0 0 0}$ & $\mathbf{2 0 0 6}$ & $\mathbf{2 0 0 9}$ & $\mathbf{2 0 1 2}$ & $\mathbf{2 0 1 5}$ & $\mathbf{2 0 1 8}$ \\
\hline \multirow{2}{*}{$\begin{array}{l}\text { Share in global } \\
\text { export* }\end{array}$} & EU & 38.0 & 38.8 & 37.5 & 32.2 & 33.8 & 34.6 \\
\cline { 2 - 8 } & India & 0.8 & 1.3 & 2.4 & 2.0 & 2.0 & 2.1 \\
\hline $\begin{array}{l}\text { Share in global } \\
\text { import }\end{array}$ & EU & 37.7 & 38.9 & 37.1 & 31.5 & 31.9 & 32.8 \\
\cline { 2 - 8 } & India & 0.8 & 1.6 & 2.2 & 2.6 & 2.2 & 2.6 \\
\hline $\begin{array}{l}\text { Share of services } \\
\text { in export }\end{array}$ & EU & 23.8 & 25.0 & 27.9 & 26.2 & 29.2 & 29.4 \\
\cline { 2 - 8 } & India & 27.8 & 35.9 & 34.6 & 32.3 & 36.5 & 38.2 \\
\hline $\begin{array}{l}\text { Export to GDP } \\
\text { ratio }\end{array}$ & EU & 34.3 & 37.8 & 34.8 & 42.2 & 43.2 & 44.8 \\
\cline { 2 - 8 } & India & 13.0 & 21.3 & 20.4 & 24.5 & 23.0 & 19.7 \\
\hline
\end{tabular}

* Terms "export" and "import" generally refer to export and import of goods and services. Source: author's own elaboration and partially calculations according to: [www 5; www 6 , www 7].

One of the most important measures of "internationalisation" of the economy is the share of export of goods and services in the gross domestic product. As it transpires from table 1, the differences between the European Union and India in that respect are considerable. In the second decade of the 21st century, the share of export in the GDP of the European Union was almost twice as high as in India and, moreover, it systematically increased (with the exception of the 2008-2009 economic crisis). On the other hand, in India, this indicator has dropped along with the GDP growth rate also decreasing in the last years of the second decade of this century. This indicates a slowdown in the dynamics of Indian foreign trade development, 
which was high in the initial part of this century. This aspect will be discussed further in the article.

The first two decades of this century have seen a significant increase in international goods turnover. If the turnover in 2000 is treated as $100 \%$, then in the case of export from the European Union in 2018, the growth rate was $269 \%$, while for India it amounted to $768 \%$. As a result of the high rate of growth, the share of goods export from India increased in the years $2000-2018$ from $0.7 \%$ to $1.7 \%$ of world goods export [www 6, author's own calculations]. It should be added that the growth of Indian export was more regular than that of the European Union, which showed a highly volatile dynamic in this century. After a large decline in 2009 (the global financial crisis), as well as drops (but on a smaller scale) in the years 20152016, there were high increases in the remaining years of the period considered. A similar volatility of the growth rate was observed in import of goods to the European Union and India.

\section{Trade in goods}

As far as the role of the European Union and India in mutual trade is concerned, it differs for each party. In the second decade of the 21 st century, the EU became India's largest trading partner (exports + imports), with - as mentioned before - imports from the EU falling to the second place after China. The EU is the largest recipient of Indian goods. However, in the ranking of the European Union's trade partners, India is only on the 9th place [www 1].

Table 2 presents the basic indicators of trade in goods between the European Union and India.

TABLE 2

Trade in goods between the European Union (EU-28) and India

\begin{tabular}{|c|c|c|c|c|c|c|c|}
\hline \multirow{2}{*}{$\begin{array}{r}\text { Trade } \\
\text { in goods }\end{array}$} & \multicolumn{3}{|c|}{ Export } & \multicolumn{3}{|c|}{ Import } & \multirow[b]{2}{*}{$\begin{array}{c}\text { EU-India } \\
\text { trade } \\
\text { balance } \\
(\text { bln } €)\end{array}$} \\
\hline & $\begin{array}{c}\text { EU } \\
\text { export } \\
\text { to India } \\
(\text { bln } €)\end{array}$ & $\begin{array}{c}\text { India's } \\
\text { share in } \\
\text { EU } \\
\text { export } \\
(\%)\end{array}$ & $\begin{array}{c}\text { EU's } \\
\text { share } \\
\text { in India } \\
\text { export } \\
(\%)\end{array}$ & $\begin{array}{c}\text { EU } \\
\text { imports } \\
\text { from } \\
\text { India } \\
\text { (bln } € \text { ) }\end{array}$ & $\begin{array}{c}\text { India's } \\
\text { share } \\
\text { in EU } \\
\text { import } \\
(\%)\end{array}$ & $\begin{array}{c}\text { EU's } \\
\text { share in } \\
\text { India's } \\
\text { import } \\
(\%)\end{array}$ & \\
\hline 2000 & 13.7 & 1.6 & 26.3 & 12.9 & 1.3 & 22.4 & +0.8 \\
\hline 2003 & 14.6 & 1.7 & 22.6 & 14.1 & 1.5 & 20.9 & +0.5 \\
\hline 2004 & 17.2 & 1.8 & 22.7 & 16.4 & 1.5 & 19.3 & +0.8 \\
\hline 2005 & 21.3 & 2.0 & 21.9 & 19.1 & 1.6 & 17.3 & +2.2 \\
\hline 2006 & 24.2 & 2.1 & 22.4 & 22.6 & 1.7 & 17.4 & +1.6 \\
\hline 2007 & 29.2 & 2.4 & 21.3 & 26.7 & 1.8 & 16.1 & +2.5 \\
\hline 2008 & 31.4 & 2.0 & 21.2 & 29.6 & 1.9 & 15.3 & +1.8 \\
\hline 2009 & 27.5 & 2.5 & 21.4 & 25.5 & 2.1 & 14.2 & +2.0 \\
\hline
\end{tabular}




\begin{tabular}{|c|c|c|c|c|c|c|c|}
\hline \multirow{2}{*}{$\begin{array}{r}\text { Trade } \\
\text { in goods }\end{array}$} & \multicolumn{3}{|c|}{ Export } & \multicolumn{3}{|c|}{ Import } & \multirow[b]{2}{*}{$\begin{array}{c}\text { EU-India } \\
\text { trade } \\
\text { balance } \\
\text { (bln } € \text { ) }\end{array}$} \\
\hline & $\begin{array}{c}\text { EU } \\
\text { export } \\
\text { to India } \\
(\text { bln } €)\end{array}$ & $\begin{array}{c}\text { India's } \\
\text { share in } \\
\text { EU } \\
\text { export } \\
(\%)\end{array}$ & $\begin{array}{c}\text { EU's } \\
\text { share } \\
\text { in India } \\
\text { export } \\
(\%)\end{array}$ & $\begin{array}{c}E U \\
\text { imports } \\
\text { from } \\
\text { India } \\
\text { (bln } € \text { ) }\end{array}$ & $\begin{array}{c}\text { India's } \\
\text { share } \\
\text { in EU } \\
\text { import } \\
(\%)\end{array}$ & $\begin{array}{c}\text { EU's } \\
\text { share in } \\
\text { India's } \\
\text { import } \\
(\%)\end{array}$ & \\
\hline 2010 & 35.0 & 2.6 & 20.2 & 33.5 & 2.2 & 13.4 & +1.5 \\
\hline 2011 & 40.6 & 2.6 & 18.5 & 39.9 & 2.3 & 12.1 & +0.7 \\
\hline 2012 & 38.6 & 2.3 & 17.2 & 37.5 & 2.1 & 11.6 & +1.1 \\
\hline 2013 & 36.0 & 2.1 & 16.8 & 36.8 & 2.1 & 10.7 & -0.8 \\
\hline 2014 & 35.7 & 2.1 & 16.5 & 37.2 & 2.2 & 11.1 & -1.5 \\
\hline 2015 & 38.1 & 2.1 & 15.9 & 39.5 & 2.3 & 11.0 & -1.4 \\
\hline 2016 & 37.8 & 2.2 & 17.0 & 39.3 & 2.3 & 11.6 & -1.5 \\
\hline 2017 & 41.7 & 2.2 & 17.1 & 44.0 & 2.2 & 11.0 & -2.3 \\
\hline 2018 & 45.7 & 2.3 & 17.7 & 45.8 & 2.3 & 10.3 & -0.1 \\
\hline
\end{tabular}

Source: author's own elaboration and partially calculations according to: [www 1; www 3].

From 2000 to 2018, export from the EU to India increased significantly. In 2018, it was more than three times higher (334\%) than in 2000 (in current prices). Despite the high dynamics, which is the evidence of intensified economic contacts, the share of India in the EU goods exports increased only slightly, and it did not exceed $2.5 \%$ at the end of the second decade of the 21 st century. This is obviously an incredibly low indicator for the EU's economic contacts with the second demographically most populous country in the world, whose GDP ranks third in the world.

The EU-India trade relationship appears completely different as seen from the Indian side. The EU is the largest recipient of Indian goods. In the first decade of this century, more than $20 \%$ of goods exported from India were received by the EU countries, but in the following years this share decreased to $16-17 \%$.

The value of EU goods imported from India is similar to the value of export. In the years 2000-2012, the export of EU goods to India slightly exceeded the import from this country $(5 \%-10 \%)$, while in the second half of the decade the situation changed and India has recorded a surplus in trade in goods with the European Union (however, not exceeding 5\% of import) [Felbermayr et al., 2016, p. 9].

The share of India in the EU import is similar to the share in export, i.e. in the second decade of this century it was at the level of $2.0 \%-2.3 \%$. The share of the European Union India's imports is several times higher, although this indicator systematically decreased, from about $20 \%$ in 2000 to $10 \%$ in 2018; this is the effect of the aforementioned geographical reorientation of Indian foreign trade.

A more accurate picture of trade in goods between the European Union and India can be obtained by comparing the trade structure with respect to the range of products in the second decade of this century, however such representation of this phenomenon is not going to be accurate due to a significant aggregation of goods of respective sectors. Table 3 provides data for such analysis. 
The figures in table 3 show significant differences in the structure of trade in goods between the European Union and India ${ }^{3}$. The analysis of the export structure shows (average values for both compared years, i.e. 2015 and 2018) that in the EU export to India, nearly $85 \%$ of the value of goods is related to the manufacturers, while raw materials represent about $12 \%$ (other goods constitute ca. 3\%). The main group of goods, i.e. ca. $40 \%$, exported from the EU to India are machines and equipment. Other semi-manufacturers (approx. 20\%) and chemicals (approx. 13\%) are on further places. Due to the identity of the EU exports to India with the India's imports from the EU, the above indicators mean that nearly $40 \%$ of EU products imported to India are machines and equipment, followed by other manufacturers (ca. 20\%) and chemicals (about 13\%). The share of agricultural products, textiles and clothing in EU exports to India is exceptionally low, as it constitutes less than $4.5 \%$ (food $-1.5 \%$, textiles and clothing $-0.8 \%$ ). This is mainly the result of protecting the Indian market against the inflow of European agricultural and clothing products.

TABLE 3

Sectoral structure of trade in goods between the European Union (EU-28) and India (by value in $€-$ current prices, in \%)

\begin{tabular}{|l|c|c|c|c|}
\hline \multirow{2}{*}{ Years } & \multicolumn{2}{c|}{ EU export to India } & \multicolumn{2}{c|}{ EU import from India } \\
\cline { 2 - 5 } & $\mathbf{2 0 1 5}$ & $\mathbf{2 0 1 8}$ & $\mathbf{2 0 1 5}$ & $\mathbf{2 0 1 8}$ \\
\hline Total*: & 100.0 & 100.0 & 100.0 & 100.0 \\
\hline I. Primary products, of which: & $\mathbf{1 2 . 6}$ & $\mathbf{1 2 . 0}$ & $\mathbf{1 6 . 6}$ & $\mathbf{1 8 . 5}$ \\
\hline $\begin{array}{l}\text { - Agricultural products and raw ma- } \\
\text { terials, of which: }\end{array}$ & 3.2 & 3.4 & 10.0 & 8.7 \\
\hline - Food & 1.5 & 1.4 & 8.6 & 7.4 \\
\hline $\begin{array}{l}\text {-- Fuels and mining products, of } \\
\text { which: }\end{array}$ & 9.4 & 8.6 & 6.6 & 9.8 \\
\hline -- ores and other minerals & 3.4 & 3.3 & 0.8 & 0.9 \\
\hline -- fuels & 0.9 & 1.8 & 0.9 & 7.1 \\
\hline -- non-ferrous metals & 5.4 & 3.5 & 5.4 & 1.8 \\
\hline II. Manufactures, of which: & $\mathbf{8 3 . 9}$ & $\mathbf{8 5 . 3}$ & $\mathbf{8 2 . 6}$ & $\mathbf{8 1 . 0}$ \\
\hline - Iron and steel & 2.8 & 2.2 & 4.5 & 6.7 \\
\hline - Chemicals, of which: & 13.3 & 13.7 & 16.3 & 16.7 \\
\hline -- pharmaceuticals & 2.1 & 2.6 & 3.9 & 4.1 \\
\hline - Other semi-manufacturers & 21.7 & 18.2 & 13.5 & 12.8 \\
\hline $\begin{array}{l}\text { - Machinery and transport equip- } \\
\text { ment, of which: }\end{array}$ & 38.1 & 43.2 & 16.7 & 17.4 \\
\hline $\begin{array}{l}\text {-- office, telecommunication and } \\
\text { electronic data processing equipment }\end{array}$ & 4.1 & 3.0 & 1.0 & 0.8 \\
\hline
\end{tabular}

\footnotetext{
${ }^{3}$ It has been assumed that the total EU exports to India = total India's imports from the EU, and vice versa.
} 


\begin{tabular}{|l|c|c|c|c|}
\hline \multirow{2}{*}{ Years } & \multicolumn{2}{c|}{ EU export to India } & \multicolumn{2}{c|}{ EU import from India } \\
\cline { 2 - 5 } & $\mathbf{2 0 1 5}$ & $\mathbf{2 0 1 8}$ & $\mathbf{2 0 1 5}$ & $\mathbf{2 0 1 8}$ \\
\hline $\begin{array}{l}\text {-- transport equipment and machin- } \\
\text { ery, of which: }\end{array}$ & 9.3 & 14.1 & 5.5 & 5.2 \\
\hline --- automotive products & 3.5 & 3.1 & 3.5 & 2.9 \\
\hline -- other machinery & 24.7 & 26.0 & 10.3 & 11.4 \\
\hline - Textiles & 0.6 & 0.5 & 6.2 & 5.8 \\
\hline - Clothing & 0.2 & 0.3 & 14.5 & 11.7 \\
\hline - Other manufacturers & 7.2 & 7.2 & 10.9 & 10.0 \\
\hline III. Other products & $\mathbf{3 . 5}$ & $\mathbf{2 . 7}$ & $\mathbf{0 . 8}$ & $\mathbf{0 . 5}$ \\
\hline
\end{tabular}

* product classification according to SITC

Source: author's own calculations according to: [www 2].

However, the structure of Indian export to the EU differs significantly from that of EU export to India. It is dominated by the textile and clothing sector with the share of $17 \%-21 \%$ of total Indian export to the EU, while machinery and equipment, similarly to chemicals, account for $16 \%-17 \%$. The share of agricultural products $(9 \%-10 \%)$ and especially food $(7 \%-8 \%)$ exports from India to the EU is also high. Such a structure is characteristic for the exchange of goods between highly developed countries and developing countries.

To sum up, in the first twenty years of the 21st century, there has been a rapid development of trade in goods between the European Union and India. However, despite the high dynamics of exchange, there have been no significant structural changes in the India-EU trade [Bywalec, 2011]. Such trade exchange plays different roles in the economies of both partners. For India, trade with the European Union is of great importance, although it is systematically decreasing (especially with respect to imports). On the other hand, for the European Union, the role of trade with India is small (less than $2.5 \%$ of its total turnover). One of the conclusions is that India, although possessing huge purchasing potential both in consumption and in production, is still an area poorly used for economic expansion by European countries.

\section{Trade in services}

An outstanding feature of trade between the European Union and India is the high share of services. As it transpires from table 4 , in the second decade of the 21 st century, services account for $25 \%-30 \%$ of mutual trade. It would not be surprising if both economic entities were similar in terms of GDP value, the level of economic development or their share in world foreign trade, which is not the case (see table 1).

Table 4 summarises the indicators for the share of services in trade between the European Union and India. The differences between the EU and India's shares of global exports of services are vast. However, after 2000, this gap has experienced a 
reduction. The EU share in world exports is almost constant at the level of $41-43 \%$, while in the case of India it has grown, from $2.3 \%$ to $3.5 \%$. As for the share of services in mutual trade, the indicators are comparable, i.e. 25\%-30\% (slightly higher in India). The balance of trade in services was positive for the EU until the middle of the second decade of this century, however after 2015 the situation has changed and imports of services from India exceeded their exports to this country, so the positive EU balance turned negative. At the end of the second decade of the 21 st century, India ranked fourth as the service provider to the European Union, while in EU exports, India has been ranked sixth [www 2].

TABLE 4

\section{Trade in services between the European Union (EU-28) and India (current prices, in \%)}

\begin{tabular}{|c|c|c|c|c|c|c|c|c|c|}
\hline \multirow{2}{*}{ Years } & \multicolumn{2}{|c|}{$\begin{array}{c}\text { Share } \\
\text { in global } \\
\text { exports of } \\
\text { services }(\%)\end{array}$} & \multicolumn{3}{|c|}{ EU exports to India (bln $€$ ) } & \multicolumn{3}{|c|}{$\begin{array}{l}\text { EU imports from India } \\
\text { (bln } €)\end{array}$} & \multirow{2}{*}{ 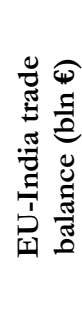 } \\
\hline & EU & India & $\begin{array}{l}\text { Goods } \\
\text { and } \\
\text { services } \\
\text { in total }\end{array}$ & $\begin{array}{c}\text { of } \\
\text { which } \\
\text { services }\end{array}$ & $\begin{array}{c}\text { Share of } \\
\text { services } \\
(\%)\end{array}$ & $\begin{array}{l}\text { Goods } \\
\text { and } \\
\text { services } \\
\text { in total }\end{array}$ & $\begin{array}{c}\text { of } \\
\text { which } \\
\text { services }\end{array}$ & $\begin{array}{l}\text { Share } \\
\text { of ser- } \\
\text { vices } \\
(\%)\end{array}$ & \\
\hline 2006 & 41.1 & 2.3 & 31.5 & 7.3 & 23.7 & 29.8 & 7.2 & 24.2 & +0.1 \\
\hline 2009 & 43.6 & 2.5 & 36.1 & 8.6 & 23.8 & 34.1 & 8.6 & 25.2 & 0.0 \\
\hline 2015 & 42.2 & 3.1 & 53.3 & 15.2 & 28.5 & 54.6 & 15.1 & 27.7 & +0.1 \\
\hline 2016 & 42.3 & 3.2 & 52.2 & 14.4 & 28.6 & 55.0 & 15.7 & 28.5 & -1.3 \\
\hline 2017 & 43.1 & 3.4 & 58.3 & 16.6 & 28.5 & 61.1 & 17.1 & 28.0 & -0.5 \\
\hline 2018 & 43.3 & 3.5 & 62.4 & 16.7 & 26.8 & 65.1 & 19.3 & 30.6 & -2.6 \\
\hline
\end{tabular}

Source: author's own elaboration and calculations according to: [Bywalec, 2011; www 1; www 7].

The high share of export of services in India's foreign trade is an extremely unusual phenomenon for a developing country, despite its dynamic development. After 2000, services have become the main carrier of economic growth in India, and their rapid development is considered a peculiarity of the country's economy [Majumdar, 2012, pp. 217-220]. India is an example of a country which, in order to catch up with the setbacks during the first decades of its independence, failed to focus (like most developing countries) on industrial development, but tried to develop intensively the service sector. In the $1990 \mathrm{~s}$, the Indian authorities formulated a programme for the rapid development of modern service sectors and thus achieved international competitive advantages ${ }^{4}$. The implementation of the programme, signifi-

\footnotetext{
${ }^{4}$ The acceleration of Indian economy servitisation, foreign trade and foreign direct investments results from [Bywalec, 2015, p.181]:
} 
cantly intensified after 2000, have confirmed the validity of its assumptions. India has become one of the world's largest generators and exporters of state-of-the-art services and, thus, it is rapidly increasing its share in the international work division [Wróbel, 2013, pp. 332-347].

Between 2017-2019, the highest share in the total Indian exports of services (with respect to the average value for this period) belonged to services related to telecommunications, computers and information (ICT) (41\%-47\%), business (19\%-20\%), tourism (14\%-15\%), and transport (9\%-10\%). In total, these four groups account for about $90 \%$ of Indian exports of services [www 4, author's own calculations]. These services are highly competitive on world markets not only due to their modernity, but also due to their favourable prices (resulting mainly from wages being lower in India than in most of the importing countries). As previously mentioned, it also results from a high standard in Indian education, and availability of well-educated English-speaking staff in roles such as computer scientists, engineers, economists, architects and managers ${ }^{5}$.

The structures of the mutual exchange of services between the European Union and India are quite different. In the middle of the second decade of this century, the leading services exported from the EU to India included: transport services (27\%$30 \%$ ), business services (26\%-30\%), ICT services (17\%-20\%), and tourism services $(12 \%-15 \%)^{6}$. These four sectors in total account for $80 \%-90 \%$ of EU export of services to India. On the other hand, the structure of Indian export of services to the $\mathrm{EU}$ is as follows: business services $38 \%-40 \%$; ICT services $21 \%-25 \%$; tourism services 17\%-20\%; transport services 16-18\% [Felbermayr, 2016, p. 39-40, partially author's own calculations].

Offshoring, called international outsourcing, has become the basic form of export of Indian services; India has become a world leader in that field [Gomułka, 2016, pp. 118-130]. Offshoring services performed by Indian companies for EU entities concern in particular areas such as: financial and accounting services (e.g.

- liberising trade in services and facilitating access to the service sector for foreign companies;

- support for the service sector from the government, i.e. in particular, a cooperation of the central state and regional authorities in creating special zones for the development of modern services (e.g. technology parks);

- favourable law for foreign investments in the service sector and preferential tax policy in relation to modern service industries;

- rapid liberalisation and modernisation of the financial sector (banks, insurance, stock exchanges) and transport;

- IT revolution, i.e. a dynamic development of IT and telecommunications services;

- rapid development of biotechnology and the electronic sector, which allowed for the production and export of modern services;

- dynamic development of IT education, i.e. education of highly qualified staff, their high mobility and adaptation to international business standards (e.g. fluency in English).

${ }^{5}$ Education of data processing specialists has a long history in India, as the first IT universities were founded in the early 1950s. Some of them are among the best in the world and their graduates are sought after IT specialists in all countries.

${ }^{6}$ Due to differences in the volume of exchange of services between years, they are rounded off as averages for several years. 
keeping financial records, financial analyses, settlement of commercial transactions, tax calculation), biotechnology services (e.g. testing of medicines), telemarketing (e.g. running a call centre), medical services (e.g. analysis of laboratory test results, medical consultations, medical counselling via the Internet), consulting services, education (e.g. teaching via Internet), design services (e.g. development of construction designs, also designs of equipment and/or consumer items). Therefore, offshoring is a highly beneficial form of international cooperation for both business partners. Thanks to offshoring, EU companies (clients of provided services) significantly reduce the costs of their operations, while the service providers on the Indian side raise capital for further investments and, most importantly, create locally well-paid jobs for highly qualified employees.

\section{Geographical structure of trade in goods}

An important element in analysing trade relations between the European Union and India is to understand the share of each Member State in mutual trade in goods. This analysis is based on statistical data summarised in table $5^{7}$.

Table 5 indicates that in the second decade of this century, among the Member States of the European Union, India's largest trading partners are: Germany, the United Kingdom, Belgium and the Netherlands, although in a different order depending on whether the analysis concerns exports or imports. The EU export to India is dominated by the UK with $16 \%-19 \%$ of the EU total export, followed by Germany (15\%-16\%), the Netherlands (13\%-17\%) and Belgium (11\%-14\%). The share of the other large EU economies, such as France, Italy and Spain, ranges from $6 \%$ to $10 \%$. In this context, Poland's performance is quite low (ranked 6 th or 7 th among EU economies). The goods from Poland constitute about $1.5 \%$ of the total EU exports to India. At the same time (cf. footnote 5), the above indicators show the spatial distribution of Indian imports from the European Union (ranging from $2.5 \%$ to $7.0 \%$ ).

Germany is the main consumer of Indian goods among the EU countries accounting for $26 \%-27 \%$ of total import from India. It is followed by Belgium (17\%$22 \%)$. The United Kingdom is the third largest consumer of Indian goods $(10 \%$ $13 \%)$. With respect to the EU import from India, the next two positions belong to France and Italy (8\%-10\%), followed by the Netherlands, Spain and Sweden (2.5\%$7.0 \%$ each). Poland's share in the EU imports from India does not exceed 1.0\%.

It is quite evident that the European Union's trade with India is dominated by large economies that belong to the "old Union". The remaining 20 EU countries account for about $10 \%$ of the trade with India, with respect to both export and import.

\footnotetext{
7 Table 5 presents only the share volume of individual states in the EU export and import. But these numbers also express the volume of India export and import (EU export to India = India import from the EU, and vice versa).
} 
TABLE 5

\section{Geographical structure of trade in goods between the European Union and India}

\begin{tabular}{|l|c|c|c|c|c|c|}
\hline \multirow{2}{*}{ EU Member States } & \multicolumn{3}{|c|}{ EU exports to India (in USD) } & \multicolumn{3}{c|}{$\begin{array}{c}\text { EU imports from India } \\
\text { (in USD) }\end{array}$} \\
\cline { 2 - 7 } & \multicolumn{3}{|c|}{ Share in EU exports to India } & \multicolumn{2}{c|}{$\begin{array}{c}\text { Share in EU imports from India } \\
\text { (\%) }\end{array}$} \\
\cline { 2 - 7 } & $\mathbf{2 0 1 2}$ & $\mathbf{2 0 1 5}$ & $\mathbf{2 0 1 9}$ & $\mathbf{2 0 1 2}$ & $\mathbf{2 0 1 5}$ & $\mathbf{2 0 1 9}$ \\
\hline Germany & 15.0 & 15.1 & 15.6 & 27.4 & 26.4 & 26.3 \\
\hline The United Kingdom & 16.2 & 18.9 & 16.2 & 13.7 & 10.0 & 13.2 \\
\hline The Netherlands & 17.3 & 12.6 & 15.6 & 4.3 & 5.4 & 7.0 \\
\hline Belgium & 13.9 & 11.3 & 11.6 & 17.9 & 21.8 & 17.4 \\
\hline France & 8.7 & 10.1 & 9.2 & 6.8 & 9.1 & 11.3 \\
\hline Italy & 9.2 & 10.1 & 8.8 & 9.4 & 8.3 & 8.8 \\
\hline Spain & 5.8 & 6.3 & 7.5 & 3.4 & 3.6 & 2.7 \\
\hline Sweden & 1.7 & 1.3 & 1.2 & 3.4 & 3.5 & 2.6 \\
\hline Poland & 1.7 & 1.3 & 1.2 & 0.9 & 0.9 & 1.8 \\
\hline Other countries & 11.5 & 13.0 & 13.1 & 12.8 & 11.1 & 8.9 \\
\hline
\end{tabular}

Source: author's own calculations according to: [India. Economic Survey 2012-2013, p. A-92, A-97; India. Economic Survey 2016-2017, p. A-107, A-115; India. Economic Survey 2019-2020, p. A-113, A-122].

\section{Conclusions}

According to the analysis of trade between the European Union and India carried out in this article, the following conclusions can be drawn:

1. After 2000, there has been a high dynamic of economic cooperation between the European Union and India. This has resulted from the process of establishing and strengthening contacts at the level of the highest authorities of the European Union and India, including annual EU-India summits, which were initiated in the 1960s. In the years 2007-2012, negotiations on the establishment of the EU-India Free Trade Area were conducted. However, due to the significant differences between the two sides, the negotiations were not successfully concluded, and no further discussions took place in 2013. Negotiations were resumed in 2016 and it now seems plausible that the negotiations will be successfully concluded and that this great trade project, involving 1.8 billion inhabitants of both economic partners, can be completed.

2. Trade between the EU and India, although almost balanced, is of varying importance to both parties. It is extremely important for India as the EU is the largest consumer of Indian goods, and Indian exports to the EU account 
for ca. $17 \%-20 \%$ of total Indian export. While the EU share in Indian import is smaller and is steadily decreasing, it is still sizeable and represented $10 \%$ of total import at the end of the second decade of this century.

3. The EU-India trade as seen from the EU side appears completely different. India's share in both export and import of goods is almost marginal in the EU trade (2\%-3\%). Such large differences in indicators of the share of trade in the global turnover of both partners result mainly from the uneven level of their economic development. Notwithstanding constant changes, the trade in goods between the EU and India is an exchange between a highly developed economy and a developing country (despite the dynamic nature of its development). Indian industry continues to lag behind and, with some exceptions, is not as strong as European industry, although the situation has been changing in recent years as a result of India's intensive reindustrialisation programme.

4. A notable feature of the EU-India trade is the large share of services. Services account for $25-30 \%$ of reciprocal trades. While the high share of services in EU export to India is not surprising, then the high share of services in India's export to the EU is undoubtedly a unique feature, especially as these are usually state-of-the-art services based on the offshoring formula, such as: IT, business, financial, advisory, scientific, marketing, transport and tourism. Such high levels of development (and export) of modern services is, in general, the result of the development strategy of Indian authorities adopted in the 1990s. It was recognised then that in the coming decades, modern services might become India's "specialisation", by using the main resource of India, i.e. human capital consisting of mainly young and highly educated (e.g. in IT disciplines) employees.

5. Among the Member States of the European Union, India's main trading partners are Germany, the United Kingdom, Belgium, France, the Netherlands, and Italy. These six countries account for ca. $85 \%$ of EU-India trade in goods. However, the trade between the EU countries of Central and Eastern Europe and India (including Poland) is very limited.

6. As the analysis has shown, the trade between the European Union and India is still low and inadequate with respect to the economic and demographic potential of both partners. However, it has great prospects for development; there are opportunities for the EU economic expansion in India. It is related to the fact that India will soon be the world's most populous country. Indian society is one of the youngest in the world; about $50 \%$ of its population are under 25 years old. Many Indian people study and their education is in the English language, as the largest number of Englishspeaking people live in India. India is a great reservoir of relatively inexpensive labour, both with respect to the simplest blue-collar jobs (e.g. workers, craftsmen) and the top qualified positions (e.g. computer scientists, doctors, architects, engineers, scientists, managers). In this context, attention should be paid to the dynamic development of the Indian middle class (300-400 
million people). It creates not only a large production pool, but also a vast and profound market for consumer goods. The huge consumer market, as well as the high demand for production goods (machinery and equipment) resulting from the rapid modernisation of the economy makes India one of the most important, attractive and prospective economic partners for the European Union in the 21 st century.

\section{References}

Bywalec G., 2015, Reformy ekonomiczne i polityczne a rozwó́ gospodarçy Indii (1991-2012), Wydawnictwo Uniwersytetu Łódzkiego, Łódź.

Bywalec G., 2011, Rozwój nymiany handlowej oraz bezpośrednich inwestycji miedsy Unia Europejska a Indiami, „Ekonomista”, nr 3, s. 431-445.

Domżalski S., 2017, Indie w gospodarce światowej. Stoń, który pragnat latać, Wydawnictwo Asian Century Biblioteka Jedwabnego Szlaku, Warszawa.

Felbermayr G., Mitra D., Aichele R., Gröschl J., 2016, Europe and India: Relaunching a Troubled Trade Relationship, Ifo Forschungsberichte, Leibniz Institute for Economic Research at the University of Munich, Munich, no. 8, https://www.econstor.eu/ bitstream/10419/167440/1/ifo-Forschungsberichte-80.pdf [date of entry: 20.02. 2020].

Gomułka A., 2016, Determinanty rozwoju outsourcingu w Indiach, „Prace Naukowe Uniwersytetu Ekonomicznego we Wrocławiu”, nr 448, s. 118-130, DOI: 10.15611/ pn.2016.448.09.

India. Economic Survey 2012-2013. Statistical Appendix, 2013, Government of India, Ministry of Finance, New Delhi.

India. Economic Survey 2016-2017. Statistical Appendix, 2017, Government of India, Ministry of Finance, New Delhi.

India. Economic Survey 2019-2020. Statistical Appendix, 2020, Government of India, Ministry of Finance, New Delhi.

Majumdar S.K., 2012, India's Late, Late Industrial Revolution. Democratizing Entrepreneurship, Cambridge University Press, Cambridge-New York.

Pant H.V, 2016, Indian foreign policy. An overview, Manchester University Press, Manchester.

Sing A.P., 2014, Peformance of Foreign Trade in India in the Post Liberalisation Era, "International Journal of Humanities Social Sciences and Education", vol. 1(10), pp. $11-17$.

Trade and Development Report 2019, 2019, United Nations, Geneva.

Wróbel A., 2013, Rola sektora ustug w tworzeniu gospodarki opartej na wiedzy w Indiach, „Prace Komisji Geografii Przemysłu Polskiego Towarzystwa Geograficznego”, t. 21, s. 332-347.

www 1, Countries and Regions-European Commission, 2019, https://ec.europa.eu/trade/ policy/countries-and-regions/ [date of entry: 18.12.2019]. 
www 2, European Union. Trade in goods with India, 2019, European Commission. Trade. Countries and regions, https://webgate.ec.europa.eu/isdb_results/factsheets/ country/details_india_en.pdf/[date of entry: 22.01.2020].

www 3, Government of India, 2020, Ministry of Comerce \&Industry, https:// commerce-app.gov.in/eidb/default.asp [date of entry: 17.01.2020].

www 4, Ministry of Comerce and Industry Government of India, 2020, Year Wise Services Trade data Financial Year 2016-17-2018-2019, https://www.indiaservices.in/Service-Trade-Data [date of entry: 21.02, 2020].

www 5, The World Bank, 2019, GDP, PPP https://data.worldbank.org/indicator/ NY.GDP.MKTP.PP.CD [date of entry: 19.01.2020].

www 6, The World Bank, 2019, Goods exports https://data.worldbank.org/indicator/ BX.GSR.MRCH.CD [date of entry: 23.01.2020].

www 7, The World Bank, 2019, Service Exports https://data.worldbank.org/ indicator/BX.GSR.NFSV.CD [date of entry: 26.01.2020].

www 8, The World Bank, 2019, Exports of goods and services, https://data.worldbank. org/indicator/NE.EXP.GNFS.ZS [date of entry: 12.01.2020]. www 9, The World Bank, 2019, GDP Growth, https://data.worldbank.org/indicator/NY.GDP.MKTP.KD.ZG?end=2018\&locations $=I N \&$ start $=1990$ [date of entry: 21.01.2020]. 